\title{
ANALYSIS OF SHORTCOMINGS IN IMPROVING THE COMPETITIVENESS OF THE EDUCATION MARKET
}

\author{
Feruza Haliljonovna Makhmudova
}

Assistant Department Of "Innovative Education",Tashkent State University Of Economics, Uzbekistan

\section{ABSTRACT}

This paper aims to explore the types, origins and clasification of market failure with the help of theories and experimental works of some researchers on externalities and other factors.

KEYWORDS:- Market failure, Externalities, Coase Theorem, Allocation of resources, Pegovian tax, Transaction coasts, Shadow economy.

\section{INTRODUCTION}

Market failure is an economic problem that leads to inefficient allocation of resources in the economy or in other words, it refers to incapability of an economy at given prices to reach certain intended outcomes in resource use (Islam, 2019).

\section{Literature review}

In fact, there is a strand of literature focused on the study of market failure. The studies are mainly divided into two different widespread group. The first group of scholars argue that there are six types of market failure such as noncompetitive markets, externalities, public goods, asymmetric or uncertain information, incomplete or missing markets, and macroeconomic business cycles (Dollery and
Wallis, 2001). At the same time, there are other economists who classify market failure into four features, namely externality, monopoly, public goods and common property resources (Randall, 1983).

Following the objective of the report, this section aims to discuss previous research works conducted on the study of market failure by externality.

The fundamental understandings of externalities refer to the studies of Marshall, Pigou and Coase, although they own some inconsistent senses with recent studies. In particular, Marshall's externality focuses on the influence of ongoing activities occurring in other economies, while Pigou's externalities implies the impact of global environmental factors, namely increased rates of global warming and intergenerational equity in development theory. Additionally, Coase illustrates externality with the establishments of 
CURRENT RESEARCH JOURNAL OF PEDAGOGICS 2(6): 62-67, June 2021

DOI: https://doi.org/10.37547/pedagogics-crjp-02-06-13

ISSN 2767-3278

(C)2021 Master Journals

\section{Crossref do) 8 Google}

Accepted 12thJune, 2021 \& Published 17th June, 2021

factories and their impact on fish farms, since waste water from manufacturing is negatively associated with fish livestock.

However, later in 2011, Shiqing and Jiapei summarized the research on externalities by Marshall, Pigou, Coase and other scholars and highlighted two important features of externalities; non-participatory decision-making and lacked an effective feedback mechanism. Following features, they define the externality in a comprehensive way saying that in a particular economic activity, externalities are the effects on parties that have not participated in the decision and lack an effective feedback mechanism to compensate' (cited in Jing and Sun, 2018, p151).

Earlier in 1958, a famous economist Francis Bator analyzed the causes of market failure by means of externality. In particular, he classified the externalities into three polar types, namely ownership externalities, technical externalities and public good externalities. He also adds that if economies operate ideally, dynamic markets will not be pareto-efficient the circumstances of institutions, laws, customs, or feasibility. This phenomenon persists in private venues, such as the relationship of beekeepers with orchardists, and in the public sphere, the fishing waters of the public domain.

Furthermore, Bryan Caplan categorizes the externalities into two types; merit externalities, demerit externalities. Particularly, the merit externalities are considered as costs that impossible to charge for supplying, while demerit externalities are possible. (cited in Donald, 2019). At the same time, by carrying out in-depth analysis of externality, Donald (2019) concluded that externalities do not occur in contracted arrangements when consumption or production of one actor brings the positive or negative outcome to the other one.

More particularly, some empirical studies have concentrated on the externalities resulted from
Foreign Direct Investment (hereinafter FDI) industry, mainly through the spillover effect of technology or knowledge. For instance, Hao et al. (2020) studied the impact of FDI on pollution level in 30 provinces of China as an externality. The results show that although the brought innovations thanks to FDI help reduce the emission of the sulfur dioxide and smoke dust in certain sectors, it increases the demand for oxygen substantially. Likewise, Yunus et al. (2015) investigated the positive as well as negative externalities associated with inward FDI in Malaysia. His findings report that the spillover effects of FDI play a key role in skill upgrading of labor sector, while making some part of labor force redundant due to brought technological advancements in high-level industries.

\section{Market failure: causes and government intervention}

Economic theories and studies so far attempted to explain the possible reasons for the presence of market failure in economics. By well-excepted belief, the existence of dysfunctional nature of price systems and structural imperfections are considered principal causes of market failure. They are mainly the existence of monopolistic, duopolistic or oligopolistic markets, externalities, de-merit goods, asymmetric information, weak property rights, inequality or unstable market characteristics.

To address the problems associated with market failure, the government is obliged to take significant policy measures. In particular, it could be done by either using price mechanism or legislation and force (Dollery and Wallis, 2001). For instance, as a remedy for externalities, the government might impose tax on negative externalities and subsidy to positive externalities. In terms of prices, the government may use threshold strategies on prices of certain essential goods, or in other words, it regulates 
CURRENT RESEARCH JOURNAL OF PEDAGOGICS 2(6): 62-67, June 2021

DOI: https://doi.org/10.37547/pedagogics-crjp-02-06-13

ISSN 2767-3278

(C)2021 Master Journals

\section{Crossref do) 8 Google}

Accepted 12thJune, 2021 \& Published 17th June, 2021

prices. In the provision of de-merit goods, policy makers may attempt to privatize some public sectors such as education and health care services. In terms of presence of non-competitive market features, the government should concentrate on removal of barriers into a certain market through carrying liberalization policies. To remove the negative aspects of asymmetric information, the policies should be oriented to strengthening market signals by increasing the disclosure of information, quality of standards and certification procedures. It could be done by establishing customer information centers and increasing focus on technological development (Cunningham, 2011).

\section{Coase Theorem}

In economics, the term the coase is defined as the case where two-participants of either two firms or two consumers, resource allocation is neutral, when there are no transaction costs (Aivazian and Callen, 1981). Historically, the concept of Coase Theorem initially appeared in 1960 by the paper of Coase. The paper was intended to argue against the claims of Pigou who believe that difference between private and social costs would cause to a waste of resources if government intervention were not involved to cure the cost. Coase theorem assert that outcome will be efficient, if the initial assignment of property rights is well defined and that transactions involving the exchange of rights are costless (Schweizer, 1988, p245). In other words, before Coase's seminal paper those externalities, which are at the center of environmental economics, require state intervention, especially taxation. However, since the appearance of Coase theorem, government action to address environmental externalities has been occasionally used to the resistance. The coase theorem only holds when three assumptions exist. First requirement is the absence of or at least lower transactions costs that could affect two interested parties. The second one refers to the existence of perfect information on the issue between two parties, while the third assumption imply that both parties are entitled to have equal power in negotiating. In addition, the existence of property rights is also the main feature of the theorem.

In reality, the application of Coase theorem is quite hard to observe unless the case is newsworthy. It is simply because there is no feature of government intervention involved.

One of the classical illustrations observed in the US could be the case between American Electric Power and inhabitants of Cheshire in Ohio. Since the establishment of nearby coal-fired Gavin Power Plant, the part of city population living nearby raised health concerns. As a result, the company bought most houses and homeowners were well compensated. The company paid mainly because of the principles of property rights stressing that one living nearby must not damage neighbors (Kolstad, 2011). A similar example could be seen with cases of companies Shell and Exxon that purchased the purchased houses near their company's territories after explosions at their operations. Besides, a Russian copper-nickel smelter company, Severonickel compensated around $\$ 300,000$ for the nearby Lapland Biosphere Reserve, natural area set aside for research in the natural sciences in the western part of the Kola Peninsula, northwestern Russia without any courts. Most recently, in 2010 a London skyscraper caused a number of problems for the nearby area due to its concave mirrored glass design. Particularly, it melted cars and caused a fire in shops and restaurant owing to the intense sun rays. After realizing the problem, the engineering company paid compensations for damaged items and redesigned the building, namely fitted with shading (Mullin, 2014).

Summarizing all cases above, it could be said that although dealing was associated with some 
CURRENT RESEARCH JOURNAL OF PEDAGOGICS 2(6): 62-67, June 2021

DOI: https://doi.org/10.37547/pedagogics-crjp-02-06-13

ISSN 2767-3278

(C)2021 Master Journals

\section{Crossref do) 8 Google}

Accepted 12thJune, 2021 \& Published 17th June, 2021

transactions costs, the problems were fixed without government interventions, namely no courts involvements, which represents the application of Coase theorem in real life.

\section{Pigou tax: practical applications and limitations}

In economics, firms and some consumers may not incur real or true cost of their activities. This, in turn, leads to market failure, which is mainly corrected by government intervention through placing a Pigou tax. In accordance with the International Tax foundation, the Pigouvian tax is defined as a tax lied on market transactions that cause to create an additional cost that paid by individuals who do not take a direct participation into transaction or in other words, any activities lead to a negative externality. By imposing a tax on the negative externality coming from a certain activity, the government tends to balance the price of good and its marginal cost to enable socially and economically efficient allocation of resources in the country.

In fact, the government introduces a Pigouvian tax on certain activities such as environmental pollution, detrimental substances and other activities that resemble the characteristics of negative externality. There is no doubt that today both emerging and developed countries where the size of population and the volume of manufacturing rapidly growing have already faced air pollution. To mitigate the associated costs of the externality, the governments of those countries are taking principal actions, mainly levying a Pigouvian tax on emission, particularly concerning the size and type of engine of cars and the manufacturing activity of firms. In addition, it is also common to see a gasoline tax in most countries of the world. A gasoline tax is intended to charge and the individuals who drive a car and cause to a negative externality to the third parties. The underlying action, first, discourages people from driving a private car, and secondly, the revenue generated from taxes are redistributed to correct a negative externality of a gasoline consumption. Another classical application of Pigou tax might be a tax on alcohol and tobacco products. It is mainly explained by the fact that the consumption of alcoholic beverages and tobacco products might cause to raise the health risk and other physical and mental harm to the third party.

Although the Pigouvian tax services as a mechanism to correct negative externalities of actions in the market, it has shares some shortcomings to consider. First, as stated above the amount of the Pigouvian tax should be equal to the marginal cost generated by negative externality. However, it is somewhat not practicable to measure the exact social cost of activity. For instance,

Secondly, as it is widely believed in economics, any tax placed on is distortionary. Likewise, the Pigouvian tax may also service as an incentive for parties to find an illegal way to get rid of the cost of their activities that involve negative externality.

Thirdly, from political prospective, it is hard and not optimal to introduce such a tax on certain products or activities, since some parties may have some interests in a certain industry.

The last but not least, per unit tax on production is not efficient alone to provide long-run efficiency. Its well functioning might be maintained by employing a lump sump tax or subsidy on negative and positive externalities (Carlton and Loury, 1980).

\section{Real example of market failure and government intervention}

Today the shadow economy 1 is a central macroeconomic phenomenon for almost all developing countries due to its several adverse consequences. First, it causes to reduce tax revenue, which has a direct negative impact on 
CURRENT RESEARCH JOURNAL OF PEDAGOGICS 2(6): 62-67, June 2021

DOI: https://doi.org/10.37547/pedagogics-crjp-02-06-13

ISSN 2767-3278

(C)2021 Master Journals

\section{Crossref do) 8 Google}

Accepted 12thJune, 2021 \& Published 17th June, 2021

the volume of government spending on the provision of public goods. Second, business activities under the shadow is free from tax burden, which distorts market competition and leads to inefficient allocation of goods and services. Overall, through the channels above, it deteriorates economic growth. These consequences certainly create a negative externality to the third parties who not involved in the transactions of activity.

\section{The European Commission defines it as the non-observed part of the economy, comprising:}

(1) Illegal activities where the parties are willing partners in economic transactions,

(2) Hidden and underground activities where the transactions themselves are not against the law, but are unreported to avoid official scrutiny, and

(3) Informal activities where typically no records are kept' (EY, 2016).

One of the most common aspects of shadow economy in today's world is underreporting of cash payments by sellers in retailing, which results in less tax revenue, and plausibly less government spending. Leaving it untouched for the market itself, the government cannot address the underlying issue. Therefore, the role of government is to intervene into the retailing market to correct market failure and mitigate the associated costs with its negative externality. In particular, South Korea is one of the most successful country that could address the underreporting of cash payments. Since the introduction of Value added tax (hereinafter VAT) in 1977, the government enacted the law to prevent underreporting. In accordance with law, the registry of cash payments were mandatory, and negligence of issuing receipts were subject to the penalty. In addition to this, the government compensated the consumers who submitted cash receipt reports with repayment with $1 \%$ value of purchase. Despite a great deal of effort, the government could not succeed in encouraging consumers and controlling the sellers. Therefore, turning to the year 1994, the government started providing a tax incentive for credit card, namely 0.5 percent of credit card sales credited to VAT payable for retail sellers. In addition, later in 1999, the Ministry of Finance introduced tax incentives for electronically traceable payments (hereinafter - TIETP), which provides deductions for labor income but not the income generated by doing business. The deduction rate was $10 \%$ of electronically traceable payments, within the ceiling less than 3 million won or 10 percent of yearly total labor income.

Turning to the effectiveness of the intervention, one can be noted that the volume of electronic payments increased dramatically after introduction of tax incentive policies. In particular, the volume of all electronic payment as percentage of GDP skyrocketed from $4.9 \%$ in 1999 to $34.3 \%$ in 2002 . As electronic payments increased, the size of shadow economy declined in Korea. To illustrate, in accordance with estimates of Schneider and Medina (2018), in 1998 the size of shadow economy as percentage of GDP in South Korea accounted for around 30 percent, while the number declined to nearly 26 in 2002. This positive change was mainly associated with introduced tax incentive polices outlined above. In addition, the BIS (Bank of International Settlements) stresses that the introduction of tax incentives made South Korea nearly cashless society.

\section{REFERENCES}

1. Bator, F., (1958). The Anatomy of Market Failure. The Quarterly Journal of Economics, (72), 351-379. 
2. Hao, Y et al., (2019). How do FDI and technical innovation affect environmental quality? Evidence from China. Environmental Science and Pollution Research.

3. Norhanishah, $M$ et al., (2015). Spillover effects of FDI and trade on demand for skilled labour in malaysian manufacturing industries. Asian Academy of Management Journal. 20 (2), 1-27.

4. Islam, M., (2019). Market Failure: Reasons and Its Accomplishments. International Journal of Economics and Financial Research. 5, 276-281.

5. Dollery, B., and Wallis, J. (2001). The Theory of Market Failure and Equity-Based Policy Making in Contemporary Local Government. Local Government Studies, 27(4), 59-70.

6. Randall, A. (1983). The problem of market failure. Natural Resources Journal. 23(1), 31- 132.

7. Donald, J., and Meiners, R., (2019). Externality: Origins and Classifications. 59 Nat. Resources J.

8. Coase, R., (1960). The problem of social cost. The Journal of Law and Economics, 31-44.

9. Schweizer, U., (1988). Externalities and the Coase Theorem: Hypothesis or Result? Journal of Institutional and Theoretical Economics (JITE). 144(2), 245-266.

10. Jing, W., and Sun, B., (2018). Negative externalities in the sharing economy: sources, paths and recommendations. International Journal of Crowd Science. (2), 149-163.

11. Cunningham, Sh., (2011). Understanding market failures in an economic development context. Mesopartner 